\title{
Revelation of Subprime Crisis on China's Financial System Reform and Innovation
}

\author{
Xin Gao \\ School of Marxism \\ Northeast Dianli University \\ Jilin, China 132012
}

\author{
Tao $\mathrm{Wu}$ \\ School of Marxism \\ Northeast Dianli University \\ Jilin, China 132012
}

\begin{abstract}
Since the global financial crisis caused by loan from the United States in 2008, countries all over the world have begun to think about their own financial institution. As a developing country, the pressing issue that the reform and innovation of Chinese financial system involves is to actively explore a development path suited to its own finance through drawing lessons from the experiences and lessons of other countries' financial development model.
\end{abstract}

Keywords-subprime crisis; financial institutional reform; financial system

\section{INTRODUCTION}

After countries around the world experienced the worldwide financial tsunami in 2008, they began to thoroughly analyze the domestic financial system. For growing developing countries like China, they need to construct a perfect financial system to keep steady and create lasting growth under the trend of global economic integration. The government regulation is the indispensable and most important part to realize the coordinated development of financial system and real economy. This is an urgent problem in the current financial system reform in our country.

\section{MODE SELECTION OF FINANCIAL SYSTEM}

The financial system is the basic framework of cash flow in an economy, mainly consisting of financial institutions and financial markets. This does not imply it is a simple superposition of these two parts; they are a crossed and connected combination. Given that the financial system has been relatively dominated by banking institutions and capital markets, bank-based and market-based are two modes of a financial system. These are the typical representatives of Germany and the United States.

The United States' and Germany's economic development is visible, and we cannot deny the tremendous contribution of the two financial systems to the development of our economy. They both have their own advantages. When it comes to the mode selection of our country's financial system construction, we can neither see the achievements of just one country. Nor can we simply copy their successful mode. China must choose a suitable mode of its own on the concrete national conditions, through learning

Grants Program: The Phases Fruits of "Informal Finance and Jilin Province's Economy Development Research" of Jilin Philosophy \& the Social Sciences Grants Program, No. 2013BS77 other countries' experiences and lessons in the development of the financial system.

The U.S. subprime crisis in 2008 has exposed the shortcomings in the market-oriented financial system. From the history of the financial industry's development in our country, there's much limitation in taking the U.S. marketoriented financial system. Since the reform and opening, banking institutions have played a key role in the establishment and development of the financial industry and are influenced by planned economy system and national economy. After 1983, specialized banks have experienced the shareholding system reform, and a number of independent joint-stock banks have set up and participated in the competition, so that they have established a relatively perfect bank system structure. Compared with other countries, the capital market of our country started relatively late, and the early development of banks gave priority to the regional pilot one and later to the nationwide promotion. In 1998, China Securities Regulatory Commission became the national securities and features the market supervision department, who established a unified regulatory system. Therefore, Chinese capital market was established. Due to it being in an early developmental stage, all kinds of supervision system as well as norms are not mature and wellestablished. The selection of the market-based financial system at present stage would go beyond the level of financial development in our country.

On the other hand, it also has limitations to adhere from the bank-dominated financial system in the long run. In the three decades of reform and opening, the bank-dominated financial system is stable and is sustaining. Rapid development of economy in our country has contributed greatly to the national economy sustainability, but with the advent of China's economic transition and financial deepening development process, some shortcomings have been exposed. This system works in terms of learning, promoting, and maturing the technology industry, but hinders independent innovation of the emerging industry and industrial structure improvement. The multiple banking crises that have occurred in the past 20 years have raised questions about the bank-dominated financial system model. Now, even Germany is reforming their banking system, vigorously developing and cultivating the capital market. Under such circumstances, our country should actively 
change strategies to make the market-oriented model and the bank-oriented pattern learn from each other, constructing a "complementary" developing mode between the bank and the market.

\section{TO CONSTRUCT THE "COMPLEMENTARY" DEVELOPING MODE BETWEEN THE BANK AND THE MARKET}

Since our country is still in the preliminary stage of socialism and the level of economic development is inferior to that of the developed countries, the bank plays an important role in the financial system for us. In the recent financial crisis, China's current financial system gives full play to risk-sharing, making a great contribution to withstanding the impact of the financial crisis. For financial development, the bank has an important status and role, but it is not without its drawbacks. Therefore, we need to intensify the building of the capital market. At current stage, our country practices mainly public ownership and develops diverse economic ownerships simultaneously. The stateowned large and medium-sized enterprises coexist with a number of private small and medium-sized enterprises. This should continue for a long period of time in future years, and different types or sizes of enterprises need to choose the most suitable way to configure resources. Capital market is the important channel of resource allocation and will play its given role. Banking and capital markets should maintain mutual corresponding and hastening relationships. As a joint result of the relationships, the national economy has developed fast and well so as to maintain the strong competitiveness in the international economy. We could make some suggestions:

- Improving Bank Management \& Optimizing the Credit Structure. In view of the lessons on the U.S. subprime crisis and in the face of the situation of increasingly expanded bank loans in our country, it is necessary to optimize the structure of bank credit, adjusting the structure of lending industry, restricting on loans in energy intensive and highly polluting and high pollution industry. We must strengthen the loan of high-tech industry, improving credit coverage, increasing investment in small and medium-sized enterprises, providing financing support for the development of small and medium-sized enterprises. The design of "agriculture, rural areas and farmers" commercial finance including state-owned banks, joint-stock banks and non-bank financial institutions in which enhance their policy for rural finance and the service level of "Three Rural".

- Developing Capital Market. We should standardize and develop a main board market, and in the meantime, promote the construction of the growth enterprise market, establish a multi-level capital market system, improve the issuing and trading of corporate bonds and credit rating system, establish and improve the assets mortgage, credit guarantee mechanism, and promote the development of the bond market.
- Developing the Small \& Medium-sized Financial Institutions. In order to stimulate the vitality of the financial system in China and ease the small and medium-sized enterprises' financing difficult situation, we should develop small and medium-sized commercial banks, trust companies, urban and rural credit cooperatives and other small and medium-sized financial institutions, to provide financial support for the development of small and medium-sized enterprises and create a fair market with loose policy environment for its development.

\section{Modernization OF THE FinANCIAL S YSTEM, A NEW CHALlENGE FACED By FinANCIAL SUPERVISION}

\section{A. Resolving and Preventing Bad Assets}

The large non-performing loans with high ratio and poor profitable assets in Chinese banks have been the important problem in financial development. If it cannot be resolved, it might influence the whole process of financial development. Thus, the regulation of bad assets becomes an important task, which could be carried on from two aspects:

- Speeding up Disposal of Those Formed Nonperforming Assets. The corresponding legislative support shall be provided. Secondly, the process of supervision is strengthened and each links such as the handover, evaluation, purchase shall be keep legal, compliance and information transparency, prevent loss of state-owned assets due to "moral hazard" in the process of disposal.

- Establishing the Deposit Insurance System. This system was invented by the United States in 1933, aiming to maintain the interests of depositors and restore public confidence in the bank credit when the bank suffered a liquidity crisis. Although there are many arguments about the system, it can prevent a run on the bank system of institutional arrangements. The United States, Britain, Germany, France, Japan and other developed countries have implemented this system. China should consider a trial in our country.

\section{B. Regulation of Financial Derivatives}

Financial derivatives are the core parts of the virtual economic and financial operation, which are one of the important factors resulting in a virtual capital expansion and causing the financial crisis. In 2004 the first rules for financial derivatives developed in our country. These rules are known as the Interim Measures for Management of Derivatives Trading by Financial Institutions.

- The financial mixed trend has already emerged in our country at present, and the innovation and application of the financial derivatives have been controlled by financial holding companies. We can draw lessons from the United States' "three-level supervision system" to establish government regulation, the derivatives market regulation and industry selfdiscipline management, strengthening internal control 
and authorization management to defend excessive speculation and the risk of moral hazard.

- The establishment accounting information disclosure system that are aligned with international standards enables the external personnel to get real information in a timely and accurate manner to forecast possible risks, strengthening information disclosure transparency of financial derivatives, making process supervision and control on derivatives trading.

- We shall strengthen the research of derivatives risk and establish a scientific early-warning mechanism. The research refers to the establishment of financial derivatives market access regulation, derivatives qualifications management, business scope definition of financial derivatives, and the financial derivatives markets for business on a regular basis in accordance with the regulation. We should establish a modern information system for the financial derivatives market supervision, strengthening the on-site audit and off-site supervisions on the financial institutions. From that, we can scientifically select a representative index system to be the main regulatory content.

\section{Supervision of the Foreign Financial Institutions}

To regulate foreign financial institutions, we should take the risk supervision as the core, focusing on the idea of global regulation. Most foreign banks are mixed managed, but differentiated regulatory system in our country is passive. We should set clear the competent authorities for foreign bank supervision, giving them specific legal rights for the convenience of effective supervision. Secondly, we give priority to government regulation and set up industry selfdiscipline association of foreign banks to give play to the role of social and public supervision. This allows us to form a comprehensive, systematic and all-round supervision system. Also, it gives play to the role of certified public accountants, the auditing firm and other social intermediary organizations trying cross-trade and cross-market financial supervision to increase public confidence in the banking sector and reduce regulatory vacuum.

\section{BuILDING HARMONIOUS FinANCE AND PROMOTING GROWTH AND A FAIR \& WIN-WIN SITUATION}

\section{A. Strengthening the Economy Level \& Quality of Production and Attaching Importance on Science \& Technology}

The real economy shall be vigorously developed, to improve the production efficiency and production efficiency of industry and agriculture to produce more and better products with positive innovation, new products development and new requirements. To increase domestic demand and to coordinate the proportion of domestic demand versus foreign demand will help us realize the sustainable development of economy in our country. Science and technology are the primary factors in the economic development. If taking the forefront or a leading role in science and technology development along with granting the product demand to be of rigidity, enterprises will gain excess profits. The related industries will predominate due to technology radiation and then achieve the external transfer, enhancing their ability to resist external shocks. Japan's performance has fully demonstrated the importance of science and technology to a country's economic stability in this crisis. Neither the overall independent innovation ability of Chinese economy or the importance of science and technology in production is strong enough. It may be severely affected facing external economic impact.

\section{B. Improve the Economic Structure \& Income Distribution}

We should actively promote the structural adjustment of the national economy by optimizing production way, taking a new road to industrialization, developing the third industry, and enhancing the soft power of economic competition. It can be seen from the international economic competition that material resources are not the most important indexes of the national competition, but soft elements such as the level of science \& technology culture and human capital are. Therefore, it is dire to increase investment in science, education, and culture and health to get rid of the rigid constraints of resources and environment on the economy.

We also need to deepen the division of production and make further refining by encouraging various size or types of production for the organization division. We need to make further excavating as well as satisfying people's economic needs to expand economic output. The rapid development of the financial markets and capital as a factor of production participating in distribution has widened the residents' income distribution gap. Therefore, we now advocate stimulating economic growth by boosting domestic demand and building a consumption-oriented economic structure. The first thing is to make the workers who make up the largest population proportion obtain the corresponding income so that they are able to start domestic demand consumption. Thus, the consumption-oriented economic structure is formed, solving imbalance among intra- industry, inter-industry, regions, the urban as well as rural areas, and eventually forming the pattern of harmonious development and mutual progress.

\section{CONCLUSION}

As the core of modern economy, finance is an important part of the development of a socialist market economy, the development level of which determines the international competitiveness of our country. According to the status quo of the financial system in China, there are three conceptions to create the Chinese socialistic Financial System suitable for China's national conditions. Firstly, our country develops a complementary model of a bank-dominant and marketdominant financial system. Secondly, the government plays an important role in macroeconomic regulation and control in the socialist market economy. On the third aspect, financial supervision is facing new challenges in the transforming process from the traditional financial system to modern financial system. Doing this will allow us to deal with problems like bad assets, financial derivatives 
regulation and supervision of foreign financial institutions, and to achieve economic growth. In turn, it will make a fair, win-win situation to build a harmonious finance.

\section{REFERENCES}

[1] Chen Cheng, Xu Zhichun. Study on the development path of disruptive innovation of commercial bank credit business based on Small and micro businesses [J]. Science \& Technology Progress and Policy, 2013.24.

[2] Tang Wei. Study on the problems of establishing rural microfinance system -- Based on the experience of the Rural Bank of Bangladesh [J]. World Agriculture. 2012.02. 